Anna Prorok

Uniwersytet Gdański

\title{
„Nie taki diabeł straszny jak go malują", czyli analiza porównawcza postaci diabła w baśniach polskich oraz norweskich
}

\author{
"The Devil is not so Black as He is Painted" - \\ a Comparative Analysis of the Devil Figure in Polish and Norwegian Folktales
}

The aim of the article is to analyze the devil's character in Polish and Norwegian folktales. The article describes his appearance, behaviour towards people, and shows in which situations he appears most often in fairy tales in those countries. The study is based on Asbjørnsen's (18121885) and Moes's (1813-1882) Norwegian Folktales and on folktales collected by the Polish folklorist Oskar Kolberg (1814-1890). At the end of the article the author compares the most characteristic features of the devil figures to see if the devil is so different in Poland and in Norway.

Key words: devil, folktales, Norwegian folktales, Polish folktales

Słowa klucze: diabeł, baśnie ludowe, baśnie norweskie, baśnie polskie

\section{Wstęp}

Baśnie występują we wszystkich znanych nam kulturach. Zarówno ich struktura, jak i budowa są często do siebie zbliżone, co dało takim badaczom jak Władimir Propp (1895-1970) czy Antti Aarne (1867-1925) możliwość stworzenia klasyfikacji baśni według występujących w nich motywów oraz do pewnego stopnia uniwersalnego modelu baśni magicznej. Kategorią, która pozwala rozróżniać baśnie $\mathrm{z}$ różnych kultur, są występujące $\mathrm{w}$ nich postacie najczęściej związane $\mathrm{z}$ lokalnym folklorem. Wydawać by się mogło zatem, że porównywanie pod tym względem postaci z polskich i norweskich baśni ludowych nie wykaże zbyt wielu podobieństw. Kraje te nie sąsiadują ze sobą i wcześniej nie utrzymywały między sobą silnych kontaktów, prezentują ponadto dwie odrębne kultury wyrosłe z zupełnie różnych wierzeń przedchrześcijańskich i od XVI wieku różnych konfesji: katolicyzmu i luteranizmu. Średniowieczna tradycja katolicka wrosła jednak głęboko w mental- 
ność Norwegów, co sprawiło, że w twórczości ludowej pojawiają się często postaci Marii Panny oraz świętego Olafa, które są pozostałościami po kulcie maryjnym oraz kulcie świętych. Oprócz nich pojawia się jeszcze jedna postać, która może stanowić ciekawy obiekt do porównań - diabeł. Jego postać nie występuje tak często w folklorze norweskim jak w polskim, jednakże jest wyrazista.

Obszar związany z badaniami nad baśniami ludowymi stanowi niezwykle ciekawe źródło analiz etnologicznych, kulturowych i literackich. Pozwala spojrzeć na społeczeństwo i naród z zupełnie innej perspektywy niż ta, którą dają badania nad literaturą piękną i historią, dzięki czemu można dostrzec dużo więcej elementów charakterystycznych tylko dla jednego regionu. Interesujące jest również zestawienie zawartych w baśniach wątków, postaci, schematów fabularnych itp., gdyż daje to możliwość wskazania, które elementy kultury ludowej są uniwersalne, a które związane są z lokalnym folklorem. Podjęta w tym artykule analiza i porównanie postaci diabła daje możliwość ukazania, że choć postaci fantastyczne występujące w baśniach zazwyczaj pochodzą z lokalnych tradycji, mogą one jednak w wyniku różnych czynników wykazywać ponadkulturowe podobieństwo.

Opisy diabła w niniejszej pracy zostały przedstawione w oparciu o następujące teksty literackie: zbiór baśni Petera Christena Asbjørnsena (1812-1885) i Jørgena Moe (1813-1882) Samlede eventyr (Baśnie zebrane) ${ }^{1} \mathrm{z}$ lat 40. XIX wieku oraz baśnie pochodzące z wybranych tomów dzieła Oskara Kolberga Lud. Jego zwyczaje, sposób życia, mowa, podania, przysłowia, obrzędy, gusła, zabawy, pieśni, muzyka $i$ tańce $\mathrm{z}$ drugiej połowy XIX wieku. Analizy dokonano w oparciu o dwa nurty badawcze: analizę strukturalistyczną baśni Władimira Proppa oraz pojęcie Innego (The Other) rozpatrywane we współczesnych badaniach literaturoznawczych.

\section{Proces dokumentowania baśni w Norwegii i Polsce}

Baśnie ludowe zbierane były w różnych epokach, jednak najbardziej owocny pod tym względem był wiek XIX i początek XX wieku. Wtedy wraz z rozwojem nauk literaturoznawczych zaczęto patrzeć na nie jako na osobny gatunek literacki i wprowadzać coraz mniej zmian do dokumentowanych tekstów. Pomimo że naukowcy, którzy spisywali baśnie w późniejszym okresie, w dużo większym stopniu oddawali dokładnie ich treść, w świadomości narodowej zapisały się nazwiska tych, którzy jako pierwsi podjęli się tej działalności. Ponadto w tamtych czasach

\footnotetext{
1 Wydanie baśni, w oparciu o które powstał niniejszy artykuł, jest kolejną edycją zbiorczego wydania baśni Asbjørnsena i Moe, ze zmianami w samym zapisie ortograficznym i odmianach słów w baśniach, mającymi na celu dostosowanie języka do współcześnie panujących norm. Działania przystosowujące język do zmieniających się norm zostały według Moltke Moe zlecone przez Asbjørnsena i Moe (Asbjørnsen, Moe 2015b: 557).
} 
badacze ci mieli możliwość dotarcia do dużo większej ilości utworów, gdyż w Europie baśnie z czasem były coraz bardziej zapominane.

Najbardziej znany zbiór norweskich baśni ludowych został wydany po raz pierwszy w formie zeszytów w latach 1841-1844 pod tytułem Norske Huldre-eventyr og Folkesagn. Baśnie zostały zebrane przez dwóch uczonych: Petera Christena Asbjørnsena oraz Jørgena Moe. Kilkanaście lat później baśnie zostały wydane ponownie, $\mathrm{w}$ rozszerzonej edycji. W swojej pracy norwescy folkloryści wzorowali się przede wszystkim na podejściu do problemu utrwalania baśni ludowych przyjętym przez badaczy niemieckich, Wilhelma Karla Grimma (1786-1859) i Jacoba Ludwiga Karla Grimma (1785-1863). Bracia Grimm, co prawda, zmieniali często w mniejszym lub większym stopniu treść baśni, starali się jednak zachować, na ile to było możliwe, język, którym posługiwali się bajarze, jak również nie nadawać baśniom moralizatorskiej formy. Zabiegi te sprawiły, że zebrane przez nich baśnie możemy traktować choćby po części jako efekty twórczości ludowej.

W Polsce proces zbierania ludowych pieśni czy opowieści rozpoczął się na niewielką skalę już pod koniec XVIII stulecia, jednak z powodu upadku państwa, a potem restrykcji po powstaniach narodowych uległ on wydłużeniu w porównaniu do państw zachodnich. Osobą, która miała największy wkład w tego rodzaju badania, był Oskar Kolberg (1814-1890). Jego zainteresowania twórczością ludową zaczęły się już w latach 30. XIX wieku, kiedy to zapoczątkował zbieranie pieśni i melodii. Jego największe dzieło to wspomniany już wcześniej wielotomowy Lud. Jego zwyczaje, sposób życia..., nad którym pracę rozpoczął w 1857 roku. To obszerne opracowanie obejmuje cały przekrój wytworów kultury ludowej, w tym również i baśnie. Początkowo Kolberg zmieniał język baśni na bardziej literacki, zachowując przy tym ich fabułę, jednak z czasem zapisywał je w tej samej formie, w której zostały one opowiedziane (Lam 1914: 7-19).

\section{Analiza strukturalistyczna Proppa oraz pojęcie Innego}

Władymir Propp (1895-1970), rosyjski folklorysta i badacz języka należący do nurtu strukturalistów, pod koniec lat 20. XX wieku opracował system, który w jego zamyśle miał być dla badaczy baśni tym, czym klasyfikacja Karola Linneusza dla przyrodników. Jego zdaniem istotne było, aby przed podjęciem badań folklorystycznych bądź historycznych prawidłowo zanalizować strukturę baśni. Opracowany przez niego system jest odpowiedni do analizowania tzw. baśni magicznych, czyli takich, w których występują postaci fantastyczne, magiczne przedmioty albo wydarzenia, takie jak na przykład wędrówka na koniec świata, i które są zbudowane w podobny sposób. Według Proppa każda baśń magiczna zbudowana jest 
z 31 funkcji, a w rozwoju fabuły odgrywają rolę: bohater, przeciwnik, donator, pomocnik, królewna lub jej ojciec, osoba wysyłająca bohatera oraz fałszywy bohater. W każdą rolę wpisana jest konkretna postawa postaci oraz jej wkład w fabułę. Bohater jest główną postacią w baśni, fałszywy bohater to najczęściej osoba, która poprzez oszustwo zajmuje na pewien czas miejsce bohatera. Królewna stanowi najczęściej swego rodzaju nagrodę, którą bohater otrzymuje po wypełnieniu zadań. Osoba wysyłająca nakłania lub nakazuje bohaterowi wypełnienie zadania. Donator ofiarowuje bohaterowi magiczny przedmiot lub tenże przedmiot zostaje donatorowi odebrany podstępem. Wróg to postać negatywna i przeciwnik.

Pojęcie Innego (The Other) jest natomiast związane $\mathrm{z}$ badaniami nad literaturą od końca ubiegłego stulecia ${ }^{2}$. Ma ono szerokie zastosowanie i można je odnieść również do baśni, a zwłaszcza baśni magicznej. Inny posiada magiczne zdolności i bierze udział w walce dobra ze złem. W baśniach magicznych jest najczęściej złą istotą, choć bywa również postacią dobrą lub neutralną. Nie należy ona do społeczności ludzi i jest ściśle związana z naturą, która sama w sobie jest uważana za najbardziej radykalną reprezentację Innego (Ingwersen 2008: 19-20). Warunkuje to jej silny związek z naturą, która niegdyś również postrzegana była przez ludzi jako obcy i niebezpieczny czynnik. $Z$ jednej strony zapewniała im pożywienie i wiele niezbędnych surowców, $z$ drugiej była nieprzewidywalna i niemożliwa do kontrolowania. Takie podejście wpływało na konstrukcje baśni, które przestrzegać miały nie tylko przed napotykanymi istotami, ale też przed niszczycielską siłą samej natury. Niektórzy badacze są zdania, że postacie, które w baśniach poszukują kontaktu z Innym, na przykład poprzez pragnienie bycia porwanym przez trolla do wnętrza góry, są z psychologicznego punktu widzenia osobami, które nie do końca wpisują się w ramy społeczeństwa, a nierzadko stoją niejako poza nim (Solberg 1999: 158-159). Można przypuszczać, że postać Innego lub Innych wiąże się w Skandynawii w pewnym stopniu $\mathrm{z}$ dawnymi wierzeniami przedchrześcijańskimi, na co może wskazywać choćby klasyfikowanie postaci $\mathrm{z}$ folkloru skandynawskiego, takich jak huldra ${ }^{3}, n y k k^{4}, n i s s e^{5}$ czy troll jako Innych (Ingwersen 2008: 20-27).

\footnotetext{
2 Jedną z istotniejszych pozycji poświęconych temu zagadnieniu jest: Larsen, Nojgaard, Ballegaard Petersen, eds., 1997.

3 Postać występująca w baśniach, najczęściej jako piękna młoda dziewczyna z krowim ogonem, która ukazuje się młodym mężczyznom.

4 Postać fantastyczna związana $\mathrm{z}$ wodą - jeziorami i bagnami. Potrafi zmieniać się w białego konia, który wciąga na swoim grzbiecie ludzi w topiel.

5 Istota żyjąca w gospodarstwach i domostwach, wyglądem przypominająca karła lub krasnoludka. W zależności od dobrego lub złego traktowania przez gospodarza może być albo pomocna, albo złośliwa i psotna.
} 


\section{Diabeł w baśniach norweskich}

W języku norweskim diabła oznacza słowo djevel, jednak w baśniach występuje on pod nazwą fanden bądź faen, która pochodzi od staronordyckiego słowa oznaczającego kusiciela (Fanden b.d.). Często też jest nazywany Gamle-Erik (dosł. Stary Eryk). Korzeni tej nazwy można się doszukiwać poprzez analogię ze szwedzkim odpowiednikiem jego imienia - Gamle Sjul. Szwedzkie imię Sjul jest wariantem imienia Sigurd i odnosi się prawdopodobnie do Sygurda Fafnesbane ${ }^{6}$, jednej z postaci występujących w mitologii nordyckiej. Jego imię zostało związane z diabłem przypuszczalnie po przyjęciu chrześcijaństwa po to, aby ludzie zaczęli utożsamiać wszelkie dawne wierzenia z szatanem i złem. Jest bardzo możliwe, że podobne zjawisko miało miejsce w protestanckiej Norwegii, gdzie niektóre przejawy tradycji katolickiej, na przykład kult świętych, mogły być traktowane negatywnie. W tym kontekście imię króla szwedzkiego Eryka, świętego czczonego do XVI wieku w Szwecji i Norwegii, mogło stać się w ludowych opowieściach określeniem negatywnym (Faxén 1970). Nie wiadomo dokładnie, dlaczego przyjęto imię szwedzkiego, a nie norweskiego świętego. Możliwe, że miało to miejsce z powodu wystąpienia Szwecji z unii kalmarskiej, wobec czego chciano wzbudzić negatywne uczucia nie tylko w stosunku do katolicyzmu, ale również do sąsiedniego wrogiego kraju. Pochodzenie tego imienia tłumaczy się też poprzez etymologię imienia Erik/Eirik, które pochodzi ze staronordyckiego Aginrikr oznaczającego tyrana bądź przerażającego wodza. Ponadto diabeł występuje również pod nazwami den onde - zły, styggen brzydki, uvenn - nieprzyjaciel, belsebub, puken (Sivertsen 2000: 265). Ta różnorodność nazw brała się z silnego strachu przed wypowiadaniem jego imienia: diabeł (djevel), które mogło go przywołać. Co ciekawe, w Norwegii sfera przekleństw jest związana w dużej mierze właśnie między innymi z diabłem (Moe 1993: 14).

W baśniach norweskich ze zbioru Asbjørnsena i Moe nie znajdujemy wielu opisów diabła. Zazwyczaj jest on podobny do ludzi i tylko pewne szczegóły w jego wyglądzie czy zachowaniu wskazują na to, że nie należy do rodzaju ludzkiego. W jednej z baśni czytamy na przykład, że był to „brzydki, stary człowiek - powiadają, że był to sam diabeł [tłum. A.P]" (Asbjørnsen, Moe 2015a: 155), z kolei w innym przypadku Skiperen og Gamle-Erik (Marynarz i Stary Eryk) (Asbjørnsen, Moe 2015a: 481-483) pojawia się on pod postacią podmuchu wiatru, co pokazuje, że $\mathrm{w}$ przeciwieństwie do wielu innych postaci $\mathrm{z}$ folkloru ludowego jego fizyczne ciało nie jest tak naprawdę rzeczywiste i stanowi zaledwie jedną z form, które może przybrać. Jednakże według tradycji ludowej diabeł ma różki, ciemną skórę, końskie kopyto zamiast jednej stopy i jest owłosiony (Sivertsen 2000: 265).

Sygurd Fafnesbane jest jednym $\mathrm{z}$ bohaterów pojawiającym się w pieśniach zebranych w Eddzie Starszej oraz w sagach. Jego największym dokonaniem było pokonanie smoka Fafnira. 
Miejsce zamieszkania diabła znajduje się z dala od ludzkich siedzib. Jest nim najczęściej piekło, choć bywa i tak, że mieszka on w zwyczajnym domu. Piekło znajduje się w pewnym bliżej nieokreślonym miejscu na ziemi, lecz aby tam dotrzeć, trzeba przebyć długą drogę. Jego obszaru strzegą strażnicy, którzy pilnują, aby nikt nie mógł niepostrzeżenie wejść ani wyjść przez wrota. Jest to również miejsce kary, która spotyka grzeszników po śmierci. Pomimo, a może właśnie z powodu groźnej funkcji diabła podkreślanej niegdyś przez duchownych, baśnie o diable, jak również i opisy piekła mogą budzić w słuchaczach wesołość. Tak na przykład w baśni Kvernen som står og maler på havsens bunn (O młynku, który miele na dnie morza) (Asbjørnsen, Moe 2015a: 386-390) okazuje się, że diabły mieszkające w piekle bardzo lubią wędzoną szynkę, ponieważ „w piekle wieprzowina jest rzadką strawą [tłum. A.P.]" (Asbjørnsen, Moe 2015a: 387). Inna baśń, Gutten og fanden (Chłopiec i diabeł), opowiada o chłopcu, któremu udaje się podstępem namówić diabła do skrycia się wewnątrz orzecha, następnie zgniecionego przez kowala (Asbjørnsen, Moe 2015: 90-92).

Tego typu historie mogły powstać, gdyż ludzie nie chcieli opisywać prawdziwej mocy diabła, podobnie jak często nie nazywali go prawdziwym imieniem, lecz przydomkami, aby go nie przywołać i nie przysporzyć mu siły. Zamiast tego diabeł był wyśmiewany, a jego złowroga moc zmniejszana. Znaleźć można jeden typ baśni, w których to diabeł wygrywa. To historie, których bohaterami są osoby powszechnie znienawidzone przez ludzi. Tak na przykład w baśni Fanden og futen (Diabet i poborca) (Asbjørnsen, Moe 2015b: 86-87) osobą negatywną jest nie diabeł, lecz tytułowy poborca, który zostaje porwany i zabrany do piekła w odpowiedzi na życzenia mieszkańców wsi. Choć próbuje on przekonać diabła, aby zabrał kogoś innego w jego miejsce, przegrywa.

Pod wieloma względami diabeł pełni w baśniach rolę, którą można by bez naruszania fabuły powierzyć innym postaciom $\mathrm{z}$ wierzeń ludowych, jednak występuje kilka motywów charakterystycznych tylko dla niego. Jest to przede wszystkim umowa zawierana pomiędzy nim a człowiekiem, zgodnie z którą śmiertelnik może otrzymać dowolną rzecz (przedmiot fizyczny bądź umiejętność) w zamian za oddanie diabłu swojej duszy po upływie określonego czasu. W tym celu spisany zostaje kontrakt, sygnowany przez obydwie strony. Umiejętności, które zyskuje człowiek, są często związane z jego zawodem - kowal zostaje najlepszym kowalem na świecie, a kapitan zawsze, bez jakichkolwiek szkód, wraca do portu. W baśniach, w których występuje taki element, po określonym czasie pojawia się diabeł, aby zgodnie z umową odebrać swoją własność. Jednak bohaterowi zawsze udaje się go przechytrzyć. Oprócz zwykłych ludzi umowę z diabłem zawierać mogą również czarownice, które w zamian za utratę duszy zyskują od niego magiczne umiejętności. Umowę mogą zawrzeć na przykład podczas sabatu poprzez wpisanie swojego imienia do specjalnej księgi (Asbjørnsen, Moe 2015b: 408). 
W schemacie Proppa diabeł pełni zatem rolę dawcy, choć często staje się nim mimowolnie. Ludzie uzyskują od niego dobra nie tylko na mocy kontraktu, ale również i na drodze kupna, jak choćby w baśni Kvernen som står og maler på havsens bunn, w której diabeł sprzedaje chłopu magiczny młynek, lub dzięki użyciu siły, jak Mumle w baśni Mumle Gåsegg (Mumle Gęsie Jajo) (Asbjørnsen, Moe 2015a: 95-105), który sam wziął od matki diabła daninę dla króla. Diabeł może być również wrogiem, jak na przykład w historii przytoczonej w baśni En aftenstund $i$ et proprietorkjøkken (Wieczór w gospodarskiej kuchni) (Asbjørnsen, Moe 2015a: 155-156). Mówi ona o księdzu, którego diabeł usiłował zatrzymać, gdy ten jechał $\mathrm{z}$ ostatnim namaszczeniem do kobiety prowadzącej grzeszny żywot - bez sakramentów z pewnością dostałaby się do piekła. Nie można jednak jednoznacznie stwierdzić, czy diabła można włączy do grupy tzw. Innych (Ingwersen 2008: 24). Co prawda, jego stałe siedziby znajdują się w oddaleniu od ludzkich skupisk, lecz nie jest on przez to bardziej związany z naturą niż ludzie, nie można go uważać za uosobienie jej niszczycielskich sił. Jest on za to jednoznacznie powiązany z wiarą i teologią chrześcijańską.

\section{Diabeł w baśniach polskich}

W polskich baśniach diabeł jest jedną z najpopularniejszych postaci fantastycznych. Często ma charakterystyczny wygląd: rogi na głowie, kopyta lub jedno kopyto zamiast stopy i krowi ogon. Potrafi zmienić się także w człowieka albo zwierzę. Jego ubiór zaś cechowały zagraniczne, zazwyczaj niemieckie akcenty (Rożek 1993: 200). Bywa, że jest to „jegomość niski, pękaty, z dużym nosem, w czerwonych spodniach, niebieskim fraku i rogatym kapeluszu na głowie"7 (Kolberg 1962b: 149) bądź „jegomość w czerwonym fraku, niebieskich spodniach, mający na głowie trójgraniasty kapelusz” (Kolberg 1962b: 155) lub też ma „różki na głowie, koźle kopyta u nóg i ogon niby frakiem przykryty" (Kolberg 1962b: 151). Może zmieniać się w pięknego młodzieńca (Kolberg 1969: 428), kobietę (Kolberg 1969: 588), szlachcica (Kolberg 1962b: 127; 1970: 119) oraz zwykłego mężczyznę (Kolberg 1962b: 122; 1965: 438). Przybiera również postać rozmaitych zwierząt, na przykład czarnego kozła (Kolberg 1962b: 81). Diabeł zamieszkuje bardzo różnorodne miejsca. Może oczywiście przebywać także w piekle,

W tym podrozdziale artykułu podane są odniesienia jedynie do baśni, które najtrafniej ilustrują cechy diabła, zaś wybór baśni, na podstawie których dokonano analizy, jest dużo szerszy. Wszystkie pochodzą z podanych w bibliografii dzieł Kolberga. Pewna przewaga przytaczanych baśni polskich nad norweskimi spowodowana jest tym, że materiał zebrany przez Kolberga jest znacznie obszerniejszy, a ilość baśni, w których występuje diabeł, znacznie przewyższa liczbę baśni o diable zebranych przez Asbjørnsena i Moe. 
wraz z innymi podobnymi sobie. Jest to miejsce kary, gdzie żywemu człowiekowi trudno dotrzeć, choć istnieją baśnie opowiadające o młodych chłopcach, którym diabeł ofiarował tam pracę. Musieli oni pilnować ognia pod kotłem lub garnkiem podczas nieobecności diabła. W kotle znajdowały się dusze ponoszące kary za grzechy (Kolberg 1962b: 127; 1965: 446).

Diabeł może żyć również w pobliżu ludzi, a spotkać go można praktycznie wszędzie. Istnieją także wierzenia mówiące o tym, że można go przywołać, wymawiając jedynie jego imię. W baśniach jest on nazywany najczęściej „diabłem”, słowem pochodzącym z języka greckiego. Oprócz tego określa się go mianem „kusy”, „bies”, „czart” oraz „szatan”. Słowa „bies” i „,czart” pierwotnie były nazwami słowiańskich złych duchów żyjących w lasach, na bagniskach i w głębokiej wodzie. Oprócz tego nazywa się go imionami własnymi jak Boruta oraz Rokita. Podobnie jak słowa „bies” i „czart” mają one źródło w przedchrześcijańskich wierzeniach. Imię Boruta pochodzi od słowiańskiego demona Boruty, który żył w lasach i strzegł zwierząt. Była to neutralna istota, jednak po wprowadzeniu chrześcijaństwa podobnie jak inne dawne bożki został powiązany z diabłem. Imię Rokita odnosiło się zaś pierwotnie do diabła, który rezydował w dziupli wierzby (rokita to jeden z gatunków wierzby) (Podgórscy 2005: 386). Diabły posiadały też swoją własną hierarchię, która stanowiła odzwierciedlenie trzech stanów zamieszkujących kraj: szlachty, mieszczaństwa i chłopstwa (Pełka 1987: 185).

Postać diabła występuje w różnych typach baśni. We wszystkich próbuje on pozyskać dusze lub szkodzić ludziom. Jednakże najbardziej interesują go ludzie bogaci. W jednej z baśni czytamy nawet, jak to stary diabeł pouczał młodego: „a pamiętaj durniu, że nie na tom cię posłał abyś biednym robił psoty, ale bogatym" (Kolberg 1962b: 165). Wśród baśni o diable wyróżnić można między innymi sporą grupę, w których występuje motyw porwania królewny przez diabła. Jedna z nich O żolnierzach i królewskich córkach (Kolberg 1969: 450-452) mówi o czterech żołnierzach, którzy wyruszają uratować trzy królewny porwane przez diabła. Znajdują oni w lesie studnię, przez której dno można przejść do innego świata. Jeden z żołnierzy schodzi na dno i dociera do zamku, w którym znajduje się najstarsza królewna. Wieczorem pojawia się diabeł, którego żołnierz pokonuje w walce. Następnie idzie on do kolejnego zamku, w którym znajduje się średnia królewna i walczy tam z kolejnym, dwunastogłowym diabłem. To samo ma miejsce $\mathrm{w}$ trzecim zamku, w którym więziona jest najmłodsza królewna. W baśniach norweskich o podobnym motywie miejsce diabła zajmuje troll, który staje się tym samym uosobieniem złych sił czyhających na ludzi. Inny temat baśni norweskich, gdzie troll zastępuje postać diabła, realizowany jest w podobnych baśniach polskich $\mathrm{w}$ formie próby zniszczenia kościoła przez rzut głazem albo budowy mostu. Jednakże troll nie jest przez to tożsamy z diabłem, gdyż w przeciwieństwie do tego pierwszego można go zabić, a ponadto interesuje się 
on wyłącznie ciałem człowieka, a nie jego duszą ${ }^{8}$. Ponadto w przypadku baśni o budowaniu sam schemat fabularny można cofnąć aż do historii zawartej w Eddzie Młodszej o budowie warowni Asów (Sivertsen 2000: 32)9 .

Oprócz tego wyróżnić można wiele baśni opowiadających o ludziach, którzy swoim zachowaniem sami ściągnęli na siebie moc złego, czy to wymówieniem jego imienia, czy to samym zachowaniem. Jedną z nich jest $O$ Rozynie, w której to diabeł porywa pannę, piękną i próżną, która odrzucała konkurentów starających się o jej rękę, kierując się jedynie pozycją i majątkiem mężczyzn (Kolberg 1962b: 154-155). Z kolei bohaterka baśni $O$ dziewce poślubionej diabłu ściąga na siebie zgubę, gdy przymuszona do małżeństwa, wypowiadając w kościele przysięgę małżeńską, w myślach przeklina „oj, bodajbym ja djabłu ślubowała nie tobie” (Kolberg 1962b: 158). W baśni O pastuchu (Kolberg 1962b: 143) diabeł podczas mszy obserwował wiernych i spisywał na koziej skórze ich grzechy popełnione w kościele: rozmowy i plotkowanie, ziewanie, oglądanie strojów innych osób, śmiech itp. Gdy zabrakło mu miejsca usiłował skórę siłą rozciągnąć, jednak wysunęła mu się z pazurów i uderzył głową o ścianę. Baśnie o bardzo podobnej fabule występują również w Norwegii (choć nie pojawiają się one w zbiorze Asbjørnsena i Moe), a najstarsza $\mathrm{z}$ nich znajduje się w Mariu saga, średniowiecznym skandynawskim zbiorze legend maryjnych, i opowiada o subdiakonie, który podczas mszy ujrzał diabła spisującego na skórze ludzkie grzechy. Podobnie jak w baśni krakowskiej występuje element komiczny w postaci rozciągania skóry. Tego typu opowieści były rozpowszechniane, by nakłonić ludzi do właściwego zachowania w kościele (Grambo 1990: 134-135).

Podobnie jak w baśniach norweskich pewna grupa baśni polskich opowiada o kontrakcie zawartym z diabłem. W skutek jego zawarcia człowiek zyskuje od szatana umiejętności lub majątek, a w zamian zobowiązany jest oddać mu swoją duszę po określonym w umowie czasie. Cyrograf spisany zostaje zazwyczaj na skórze i podpisany krwią z serdecznego palca. Przykładem tego typu baśni może być O strzelcu (Kolberg 1962b: 157), w której to tytułowy bohater w zamian za to, że nigdy nie wróci z niczym z polowania, ma po roku oddać diabłu duszę. Przedtem diabeł musi jednak rozpoznać zwierzę, które pokaże mu strzelec. Bohaterowi dzięki pomocy starej kobiety udaje się oszukać diabła. Okpienie diabła i uniknięcie po-

8 Podobną analogię pomiędzy ludowym obrazem diabła a biesa w Polsce zauważył Kotula (Pełka 1987: 145), jednakże obecnie wielu badaczy uważa, że bies został wchłonięty przez diabła (Podgórscy 2005: 386; Rożek 1993: 196).

9 Bogowie zlecili budowę swojej twierdzy pewnemu jotunowi (w mitologii skandynawskiej jotunowie to duże, złe istoty, wrogowie bogów i ludzi; z czasem zaczęły zanikać w wierzeniach ludowych, a w ich miejscu pojawiły się trolle) i obiecali słońce, księżyc i boginię Freyę jako zapłatę za ukończenie pracy w terminie. Gdy stało się jasne, że jotun zdąży na czas, Loki, jeden z bogów, zmienił się w klacz i uwiódł konia jotuna tak, że ten bez jego pomocy nie skończył pracy na czas i w efekcie nie otrzymał zapłaty. 
tępienia jest typowe dla baśni o takiej fabule. Z kolei w niektórych baśniach kontrakt zawarty z diabłem dotyczy obietnicy oddania mu swoich dzieci. Bohaterowie zazwyczaj nie robią tego świadomie. Za pomoc w jakiejś trudnej sytuacji obiecują oddać pomocnikowi (tzn. diabłu) to, co mają w domu, a o tym jeszcze nie wiedzą. Dopiero po powrocie orientują się, że zostali oszukani i przyobiecali diabłu nowonarodzone dziecko. Taki przebieg wydarzeń ma miejsce chociażby w baśni O chłopcu sprzedanym diabłu (Kolberg 1965: 438). Również w tego typu baśniach diabeł zostaje na końcu przechytrzony. Istnieje również szereg humorystycznych historii o współpracy baby i diabła, która dotyczy spraw, takich jak sprowadzanie innych na złą drogę lub też życia codziennego, jak na przykład wspólna uprawa zboża lub warzyw (Wojna baby z diabłem) (Kolberg 1962b: 230).

W polskich baśniach diabła można spotkać niemal wszędzie. Czai się on w lasach, przy drodze lub nawet za piecem $\mathrm{w}$ domu. Czarty posiadają rozmaite umiejętności i różnią się wyglądem, tworzą też swoją własną hierarchię, a na kształtowanie ich postaci miało z pewnością duży wpływ chrześcijaństwo i katolicyzm. Diabeł faktycznie szkodzi tym osobom, które w ogólnym pojęciu sobie na to zasłużyły, niejako wymierzając im sprawiedliwość. Przykładem tego może być baśń Diabeł i gach (Kolberg 1964: 193), w której ukarana zostaje wiarołomna żona i jej kochanek. Grzesznicy mogli być zatem pewni, że wcześniej czy później go spotkają. Po śmierci czekała ich natomiast kara w piekle. Najczęstsze było w tym wypadku palenie dusz ogniem lub gotowanie ich w kotle. Oprócz tego znajdowało się w nim tzw. „Madejowe łoże”, narzędzie tortur przygotowane specjalnie dla legendarnego zbójcy Madeja.

\section{Porównanie obrazu postaci diabła}

W baśniach norweskich diabeł jest bez wątpienia mniej popularną postacią niż w polskich, możliwe więc, że z tego powodu ilość miejsc, w których można go spotkać, jest zdecydowanie mniejsza. W części baśni miejsce diabła w fabule zajmuje „rodzimy” troll, który wywodzi się od złych istot - jotunów - z mitologii skandynawskiej. Postacie trolla i diabła posiadają jednak swoje indywidualne cechy i nie są przez badaczy utożsamiane ze sobą. Zarówno w Norwegii, jak i Polsce diabeł pojawia się na sabatach czarownic, choć w polskich baśniach tego typu opisy nie pojawiają się zbyt często, być może $\mathrm{z}$ uwagi na mniejszą skalę procesów o czary w tym kraju. W norweskich baśniach nie można zaobserwować jakiejkolwiek hierarchii czy rozróżnienia wśród poszczególnych diabłów. W przeciwieństwie do tego w polskich występuje i jedno, i drugie. Pojawia się wiele diabłów lokalnych, powiązanych $\mathrm{z}$ konkretnymi miejscami, wierzeniami czy postaciami historycznymi, jak choćby Diabeł wenecki, którym stał się po śmierci (według wierzeń 
ludowych) Mikołaj Chwałowic herbu Nałęcz, właściciel zamku w miejscowości Wenecja, czy kaszubski smętek (Pełka 1987: 189-191). Diabły polskie dzielą się też wyraźnie na warstwy społeczne będące odpowiednikami warstw w dawnym społeczeństwie polskim. W Norwegii nie istniał tak silny podział klasowy, co za tym idzie, i społeczność diabelska (o ile można o takiej mówić) nie została podzielona. Wyobrażenia piekła w baśniach norweskich i polskich do pewnego stopnia różnią się od siebie, lecz w obu przypadkach jego zasadniczą funkcją jest umożliwienie wymierzania kar duszom grzeszników po śmierci. Takie opisy podobne są do późnośredniowiecznych, pełnych chaosu, grozy, ale też i groteski wizji malarskich tego miejsca. W baśniach polskich diabeł często pojawia się, by ukarać grzeszników. Tak istotna rola diabła $\mathrm{w}$ baśniach ludowych, związana $\mathrm{z}$ karą, może wynikać z katolicyzmu, konfesji przeważającej w Polsce, gdzie szczególnie w kazaniach przez długi czas podkreślano grzeszność i winę ludzi oraz opisywano przerażające obrazy kary po śmierci. Na ścianach kościołów wierni mogli oglądać między innymi malarskie wyobrażenia piekła, kar piekielnych i odrażające postacie szatanów (Pełka 1987: 16-17). W baśniach norweskich kara za grzechy również jest motywem pojawiającym się w baśniach o diable, jednak wydaje się nie występować aż tak często jak w polskich. Możliwe również, że mniejsza częstotliwość występowania diabła w baśniach związana jest ze strachem przed jego niepotrzebnym przyzywaniem, który objawiał się dosyć silnie w unikaniu wymawiania jego imienia. Ponadto istotną przyczyną różnic w charakterze, a także popularności diabła może być też rozwój tej postaci w folklorze obu krajów związany z wierzeniami pogańskimi. Leonard Pełka napisał, że po przyjęciu chrześcijaństwa w Polsce doszło do zmian w wierzeniach ludowych, których istotną cechą było

włączenie funkcjonujących wyobrażeń demonicznych i postaci półdemonicznych do kręgu rodziny istot diabelskich. W konsekwencji tego [...] diabły i czarownice zadomowiły się pod strzechą słowiańską, a ich wyobrażenia ulegały stopniowemu wtapianiu się w lokalne tradycje kulturowe. Doszło w ten sposób do ukształtowania się całej plejady wyobrażeń diabłów słowiańskich (Pełka 1987: 17).

Podobny proces zaszedł prawdopodobnie w Norwegii, jednak tam diabeł nie połączył się z żadnymi konkretnymi postaciami z wierzeń ludowych, a jedynie wszedł do wierzeń ludowych jako najmłodsza ze znajdujących się tam istot, będąca jednak, za sprawą wiary chrześcijańskiej, niejako zwierzchnikiem wszystkich pozostałych (Sivertsen 2000: 264).

Zarówno w baśniach polskich, jak i norweskich istnieje wiele humorystycznych historii o oszukaniu diabła, chociaż w tych ostatnich nie występują opowieści o wątpliwej współpracy baby i diabła. W podaniach z obu krajów diabła jest dosyć łatwo wywieść w pole, gdyż pomimo swojej pozornej potęgi okazuje się on w rzeczywistości słaby, niezbyt rozgarnięty, a często nawet głupi. Cechy te są wynikiem 
prób rozładowania poczucia zagrożenia, jakie niosła z sobą postać diabła i wiązane z nim potępienie (Rożek 1993: 192).

Podobny jest w baśniach polskich i norweskich wygląd czarta: rogi bądź różki na głowie, kopyta zamiast stóp, jednak w baśniach norweskich nie występują silne zagraniczne akcenty w jego ubiorze. W baśniach obu krajów diabeł posiada również pewne magiczne zdolności. Potrafi zmieniać wygląd, zmniejszyć swą postać, pracować dużo wydajniej i szybciej niż ludzie itp.

W przypadku diabła norweskiego trudno jest sklasyfikować go jako jednoznacznie Innego. Może on mieszkać w lesie lub innych odludnych i niedostępnych miejscach, jednak nie jest też aż tak bardzo oddalony od ludzi. Nie wykazuje on również żadnych istotnych więzi z naturą, z którą łączone są za to inne postaci $\mathrm{z}$ wierzeń przedchrześcijańskich, jak choćby wspomniany troll. W baśniach polskich diabeł jest zdecydowanie w dużo większym stopniu Innym. Można wykazać jego związki z przyrodą, które powstały najprawdopodobniej w wyniku połączenia go z postaciami z pogańskich wierzeń. W skutek tego procesu w wyobraźni ludowej wytworzyły się rodzaje diabłów, takie jak: leśne, wodne, górskie, polne, błotne (Pełka 1987: 17). W rezultacie diabły można było spotkać wszędzie, nawet w siedzibach ludzkich.

W baśniach obu krajów postać diabła pełni jednak tę samą rolę $\mathrm{z}$ schematu Proppa - jest dawcą lub wrogiem. W polskich baśniach przyjmuje on wiele różnych ról $\mathrm{w}$ schematach fabularnych. W niektórych typach baśni występuje w miejscu norweskiego trolla. Dotyczy to przede wszystkim baśni o porwanych królewnach, które w polskich opowieściach porywane są najczęściej przez diabła lub złego ducha (Kolberg 1969: 450), a w norweskich przez trolla (Asbjørnsen, Moe 2015a: 326; 2015b: 7). Podobieństw można się doszukać nie tylko w pełnionej przez te postacie roli oraz $\mathrm{w}$ motywach i strukturze baśni, lecz również w samym wyglądzie postaci diabła i trolla. Mogą one mieć wiele głów ${ }^{10}$ i są bardzo silne. Źródeł tych podobieństw można się doszukiwać między innymi w hagiograficznej legendzie o świętym Jerzym i smoku (często wielogłowym), bardzo popularnej w średniowieczu w całej Europie. Za tym idzie w przypadku baśni norweskich utożsamianie w niektórych przypadkach postaci trolla $\mathrm{z}$ diabłem.

Powyższa analiza ukazuje, że postacie diabła w baśniach polskich oraz norweskich wykazują dużo podobieństw. Jednakże „polski” diabeł jest dużo bardziej zindywidualizowany niż „norweski”. Pojawia się też w baśniach o wiele częściej i pełni role przede wszystkim wroga i donatora, także w wielu wariantach tych ról. Diabeł jest bogatym panem, który bierze chłopów na służbę, uprawia ziemię z babą, siedzi w kościele, zapisując nazwiska grzeszników, pod postacią pięknego, bogatego

10 Choć ta cecha nie jest jednoznacznie związana z tematyką chrześcijańską, gdyż jotuny występujące w mitologii skandynawskiej i pokrewne trollom również posiadały wiele głów (Sivertsen 2000: 19). 
młodzieńca porywa kapryśną pannę itp. W samym folklorze norweskim pojawia się więcej historii związanych z diabłem, jak choćby o grze w karty, nękaniu pastora na plebanii, o diable i woźnicy itp., jednak nie wchodzą one w skład zbioru stanowiącego podstawę niniejszego artykułu i są zdecydowanie mniej liczne niż w przypadku polskich. Ponadto diabły polskie mają wiele imion i przydomków, cech oraz umiejętności, należą też do różnych klas społecznych. Tak bogata różnorodność nie występuje w folklorze skandynawskim.

\section{Podsumowanie}

Analiza ludowych baśni polskich i norweskich wykazuje, że pomimo istotnych różnic kulturowych i geograficznych pomiędzy Polską a Norwegią, jak również braku wspólnego podłoża historycznego przedstawienia postaci diabła w baśniach obu tych krajów wykazują zaskakująco dużo podobieństw. Występują w dużej mierze te same motywy i schematy budujące fabułę różnych typów baśni, a sama postać ma w przybliżeniu podobny wygląd i umiejętności. Pojęcie diabła - szatana - złego ducha pojawiło się wraz z chrystianizacją obu krajów i przeniknęło po stuleciach do kultury ludowej, dając zbliżony obraz tej postaci w folklorze obu krajów. Postać diabła w baśniach polskich jest jednak dużo bardziej różnorodna niż w podaniach norweskich. Powodów jest zapewne kilka. W Polsce diabeł wniknął $\mathrm{w}$ wierzenia ludowe, jednocześnie łącząc się z istniejącymi już postaciami, co z pewnością przyczyniło się do jego większej różnorodności, jak również częstszego występowania w baśniach. W Norwegii postać diabła nie uległa scaleniu $\mathrm{z}$ postaciami $\mathrm{z}$ rodzimego folkloru, chociaż zostały one niejako włączone $\mathrm{w}$ poczet sił nieczystych, sama zaś postać diabła została silniej niż w Polsce związana ze sferą tabu. Ponadto hierarchia diabłów w Polsce stanowiła odzwierciedlenie hierarchii społecznej panującej w kraju, w przeciwieństwie do Norwegii, w której nie istniały tak silne kontrasty pomiędzy mieszkańcami. Również różnica konfesji w obu krajach od XVI wieku miała zapewne wpływ na wizerunek diabła. Od tego czasu w luterańskich świątyniach Norwegii nie były już tak popularne rozbudowane dekoracje malarskie przedstawiające takie tematy jak piekło, a średniowieczne obrazy stopniowo usuwano. Natomiast na ziemiach polskich dawne freski i obrazy tablicowe ze szczególnie popularnym w sztuce średniowiecznej tematem Sądu Ostatecznego, zawierającego między innymi wizerunki piekła i nieba, pozostały w kościołach, pobudzając wyobraźnię wiernych. 
Bibliografia

Asbjørnsen, P., Moe, J. (2015a). Samlede eventyr. Bd. 1. Oslo: Gyldendal. Asbjørnsen, P., Moe, J. (2015b). Samlede eventyr. Bd. 2. Oslo: Gyldendal.

Blehr, O. (1974). Folketro- og sagnforskning. Bergen: Universitetsforl.

Fanden. (b.d.). W: Det Norske Akademis ordbok, https://www.naob.no/ordbofanden [dostęp: 12.10.2018].

Faxén, L. (1970). Den 23 december- Sjursmässdag. Nordisk tidskrift för vetenskap, konst och industri 46.

Grambo, R. (1990). Djevelens livshistorie. Scener fra en travel tilvorelse. Oslo: Ex libris.

Holbek, B. (1989). Tolkning af trylleeventyr. København: Nyt Nordisk Forlag Arnold Busck.

Ingwersen, N. (2008). The Scandinavian Magic Tale and Narrative Folklore. Lewiston: Edwin Mellen Press.

Kolberg, O. (1962a). Krakowskie. Cz. 3. Seria: Dzieła wszystkie. Wrocław-Poznań: Ludowa Spółdzielnia Wydawnicza, Polskie Wydawnictwo Muzyczne.

Kolberg, O. (1962b). Krakowskie. Cz. 4. Seria: Dzieła wszystkie. Wrocław-Poznań: Ludowa Spółdzielnia Wydawnicza, Polskie Wydawnictwo Muzyczne.

Kolberg, O. (1962c). Lubelskie. Cz. 2. Seria: Dzieła wszystkie. Wrocław-Poznań: Ludowa Spółdzielnia Wydawnicza, Polskie Wydawnictwo Muzyczne.

Kolberg, O. (1962d). W. Ks. Poznańskie. Cz. 7. Seria: Dzieła wszystkie. Wrocław-Poznań: Ludowa Spółdzielnia Wydawnicza, Polskie Wydawnictwo Muzyczne.

Kolberg, O. (1963). Pokucie. Cz. 3. Seria: Dzieła wszystkie. Wrocław-Poznań: Ludowa Spółdzielnia Wydawnicza,Polskie Wydawnictwo Muzyczne.

Kolberg, O. (1964). Radomskie. Cz. 2. Seria: Dzieła wszystkie. Wrocław-Poznań: Ludowa Spółdzielnia Wydawnicza, Polskie Wydawnictwo Muzyczne.

Kolberg, O. (1965). Pomorze. Seria: Dzieła wszystkie. Wrocław-Poznań: Ludowa Spółdzielnia Wydawnicza, Polskie Wydawnictwo Muzyczne.

Kolberg, O. (1966). Litwa. Seria: Dzieła wszystkie. Wrocław-Poznań: Ludowa Spółdzielnia Wydawnicza, Polskie Wydawnictwo Muzyczne.

Kolberg, O. (1969). Mazowsze. Cz. 7. Seria: Dzieła wszystkie. Wrocław-Poznań: Ludowa Spółdzielnia Wydawnicza, Polskie Wydawnictwo Muzyczne.

Lam, S. (1914). Oskar Kolberg: żywot i praca. Lwów: Macierz Polska.

Larsen, S.E., Nojgaard, M., Ballegaard Petersen, A. (eds.). (1997). In Nature. Literature and its Otherness Annelise. Odense: Odense University Press.

Moe, A.., Fosmark, K. (1993). Hekser og troll - vardøger, varsel, fabeldyr og spøkelser. Oslo: Gyldendal.

Pełka, L.J. (1987). Polska demonologia ludowa. Warszawa: Iskry.

Podgórscy, B. i A. (2005). Wielka księga demonów polskich. Leksykon i antologia demonologii ludowej. Katowice: Wydawnictwo Kos.

Propp, W. (1976). Morfologia bajki. Tłum. W. Wojtyga-Zagórska. Warszawa: Książka i Wiedza. Ramløv, P. (1977). Myter og folkeeventyr. Voesen, funktion og historik. København: Gyldendal.

Rożek, M. (1993). Diabeł w kulturze polskiej. Szkice z dziejów motywu i postaci. Warszawa-Kraków. Wydawnictwo Naukowe PWN.

Sivertsen, B. (2000). For noen troll. Vesener og uvesener i folketroen. Oslo: Andresen \& Butenschøn.

Solberg, O. (1999). Norsk folkediktning: litteraturhistoriske linjer og tematiske perspektiv. Oslo: Landslaget for norskundervisning Cappelen akademisk forl.

Solberg, O. (2007). Inn i eventyret. Norsk og europeisk forteljekunst. Oslo: Cappelen akademisk forl. 